Дичковський Степан Іванович

кандидат педагогічних наук, доцент директор інституту практичної культурології та арт менеджменту

Національної академії керівних кадрів культури і мистецтв

ORCID 0000-0003-4771-4521 227@ukr.net

\title{
НОВІ ТЕНДЕНЦІЇ КУЛЬТУРНОГО ТУРИЗМУ В ПАРАДИГМІ ДІГІТАЛ-ЕЙЧ: ВІД ІНДУСТРІЇ ВРАЖЕНЬ ДО КУЛЬТУРНОГО БРЕНДУВАННЯ
}

\begin{abstract}
Мета роботи. Полягає в дослідженні тенденцій культурного туризму в парадигмі дігітал-ейч. Методологія дослідження полягає в застосуванні історичного, бібліографічного та аналітичного методів. Наукова новизна роботи полягає у обґрунтуванні доцільності застосування технологій дігітал-ейч в індустрію культурного туризму, що дозволить формувати туристичний продукт та туристичні дестинації на основі використання культурної спадщини та іміджу територій культурного простору. Висновки. Культурні бренди ґрунтуються на історико-культурних особистостях, пам'ятниках або історико-культурні подіях, які мають відношення не тільки до культури і історії регіону, але і мають величезну вагу в історико-культурній спадщині країни. Особливо важлива роль у формуванні культурних брендів належить місцевим закладам культури, які дозволяють представити культурно-історичний, природний, туристичний потенціал території.
\end{abstract}

Ключові слова: культурий туризм, дігітал-ейч, бренд, дестинації, інтернет, культурна столиця.

Дычковский Степан Иванович, кандидат педагогических наук, доцент, директор института практической культурологии и арт менеджмента Национальной академии руководящих кадров культуры и искусcms

Новые тенденции культурного туризма в парадигме дигитал-эйч: от индустрии впечатлений к культурному брендированию

Цель работы. Заключается в исследовании тенденций культурного туризма в парадигме дигитал-эйч. Методология исследования заключается в применении исторического, библиографического и аналитического методов. Научная новизна работы заключается в обосновании целесообразности применения технологий дигитал-эйч в индустрию культурного туризма, что позволит формировать туристический продукт и туристические дистинкции на основе использования культурного наследия и имиджа территорий культурного пространства. Выводы. Культурные бренды основываются на историко-культурных личностях, памятниках или историкокультурные событиях, которые имеют отношение не только к культуре и истории региона, но и имеют огромное значение в историко-культурном наследии страны. Особенно важная роль в формировании культурных брендов принадлежит местным учреждениям культуры, которые позволяют представить культурно-исторический, природный, туристический потенциал территории.

Ключевые слова: Культурый туризм, дигитал-эйч, бренд, дистинкции, интернет, культурная столица.

Dychkovskyy Stepan, Candidate of Pedagogical Sciences, Associate ProfessorDirector of the Institute of Practical Cultural Studies and Art Management the National Academy of Leadership in Culture and the Arts branding

New trends in cultural tourism in the digital age paradigm: from the impressions industry to cultural

The purpose of the article is a study of the trends of cultural tourism in the Digital Age paradigm. The methodology of the study is to apply historical, bibliographic and analytical methods. The scientific novelty of the work is to substantiate the feasibility of using digital-technology technologies in the cultural tourism industry, which will allow to form a tourist product and tourist destinations based on the use of cultural heritage and image of the territories of the cultural space. Conclusions. Cultural brands are based on historical and cultural figures, monuments or historical and cultural events that are not only relevant to the culture and history of the region, but are also of great importance in the country's historical and cultural heritage. Particularly important role in the formation of cultural brands belongs to local cultural institutions, which allow to present the cultural, historical, natural, tourist potential of the territory.

Key words: cultural tourism, digital age, brand, destinations, internet, cultural capital.

Основна зміна, яка відбуваються в соціальній, економічній, культурній та політичній сферах, є зростання мережевого суспільства. Кола довіри, сформовані між людьми зі зв'язаними між собою пристроями, називають mesh networks, що українською звучить як чарункові мережі. Таке коло чи мережева структура іншої топології можуть стати інтеграційним інструментом для прозорості та культури відкритого коду. У сорері туризму це веде до низки взаємопов'язаних змін, які матимуть важливі наслідки в майбутньому. Одним 3 досягнень поширення інформаційних технологій стала зміна в сприйнятті простору і часу. Теле-, відео-, інтернет-комунікації як частина цифрових технологій дозволяють сучасній людині побачити, почути, долучитися до подій, що мають культурно-рекреаційне значення незалежно від того, на якій відстані, в якому часовому поясі ця подія відбувається. Цифрові технології роблять їх доступними як в економічному, так і в статусному сенсі, тим самим розширюючи рекреаційні та дозвільні можливості сучасних людей і, що важливо, нівелюючи соціальні розриви.

(С Дичковський С. І., 2019 
Мобільні технології та соціальні мережі займають вагоме місце в багатьох сферах, в тому числі й в туризмі. Сучасні туристи стали мобільнішими, регулярно «серфять» Інтернет зі своїх гаджетів. Багато фрірм, які беруть участь у туристській діяльності спілкуються з клієнтами за допомогою використання соціальних мереж та інформаційно-комунікаційних технологій [19, 211-224].

Просування або піар туризму відбувається через соціальні медіа: блоги (friendfeed.com, ЖЖ і т.д.), мікро-блоги (twitter.com), соціальні мережі (facebook.com, myspase.com, vk.com, odnoklassniki.ru та т.ін.), аудіо і відео підкасти (dometra.ru, Russian Podcasting і т.д.).

Широким розмаїттям відрізняються туристські Інтернет-ресурси - веб-сайти, портали, блоги, електронні журнали, Інтернет-путівники. Поширеним способом транслювання своїх знань і вражень про поїздку широкої аудиторії є туристські Інтернет-форуми. Віртуальні співтовариства мандрівників це своєрідні салони, в яких формуються культурні установки туристів. Основним стимулом до публічних висловлювань на Інтернет-фрорумах $€$ «конструювання позитивної ідентичності», оскільки розповіді туристів більше характеризують самих авторів, ніж місця їх подорожей [ 29, 128].

Особливо це важливо для молодих людей, для яких цифрові технології ініціюють утворення нових фрорматів соціальних просторів з новими можливостями соціальної ідентифікації. Важливим наслідком високотехнологічних трансляцій є створення умов залучення до заходів. Цифрові технології дозволяють не тільки побачити спортивні події, змагання, концерти, відвідати віртуальні музеї, але завдяки інтерактивним технологіям в деякому сенсі стати їх співучасниками. Причому рівень якості показу, трансляції настільки високий, що глядач, що спостерігає за подією з телевізора або в інтернеті, як правило, має переваги перед людьми, які сидять в концертному залі або на стадіоні. Як макротренд маркетингу вражень, варто відзначити використання соціальних мереж як відкритого каналу для спілкування споживача з брендом. Brand experience фрормує специфічний контент цього каналу. Соціальні мережі стали незамінним майданчиком, де можна показати клієнтам цінності, на які накладається враження.

Завдяки віртуалізації сучасного суспільства туризм стає свого роду глобальним мережевим медіа-проектів, представлених в Інтернеті та ЗМІ. Глобальні системи комунікації активно впливають на свідомість і поведінку людей, формуючи туристські інтереси, потреби, мотивації. Це призводить, 3 одного боку, до розвитку віртуальних подорожей, а з іншого - до використання можливостей і ресурсів Інтернету та ЗМІ в конструюванні потенційними туристами власних культурних практик просторової мобільності. Багато в чому інновації в туризмі формують цифрову, віртуальну реальність зі специфічними соціальними, культурними, споживчими практиками. Враховуючи скупчення та знос, що зачіпає багато важливих культурних об'єктів, можливість презентації культурних об'єктів у віртуальному світі дає цілий ряд цікавих можливостей. Ці розробки дозволяють споживати віртуальну версію пункту призначення без необхідності подорожувати.

Сьогодні у світі проголошені п'ять перспективних туристичних напрямків: тематичний, пригодницький, круїзний, екологічний види туризму та культурно-пізнавальний туризм, при цьому все більший пріоритет на світовому ринку туризму віддається регіонам з самобутньою і унікальною культурою, поки ще не освоєним широким колом потенційних споживачів туристичних послуг, які стають відомими завдяки культурному брендуванню.

Про бренди в області культури активно заговорили, коли культурно-пізнавальний туризм став однією з складових . Концепцій розвитку туризму і гостинності багатьох регіонів світу, в яких приділяється особлива увага трьом напрямам: маркетинг та брендинг території; мистецтво і культура як рушійна сила розвитку міст; формування туристичного продукту та туристичної дестинації на основі використання культурної спадщини та іміджу території і фрормування культурного простору [7].

Взаємини між культурою і брендами складалися найбільш вдало в тому випадку, коли творці брендів зуміли передбачити тенденції розвитку сучасної культури та добре узгодити їх з місцевою культурою. При цьому локальні бренди оцінюються набагато вище своїх глобальних конкурентів в тому, що стосується приналежності до національної культури. Бренди не лише вносять вклад в культуру через потреби, на які вони орієнтуються, а дають нові точки відліку розбудови культурних просторів, формуючи привабливий образ території [28].

Тема брендингу територій набуває все більшої популярності, зважаючи на пошук власної унікальності і ефрективної презентації для потенційних туристів - споживачів послуг матеріальної, духовної та художньої сфрер культури [6]. Бренд певного місця формується, в першу чергу, через культурні символи й образи, які можуть трансформуватися в культурні бренди. Тому Т. Ю. Бистрова зазначає, що кожен бренд є продуктом культури, отже, поняття «культурний бренд» $€$ тавтологією [4, C.85-95]. Ï̈̈ точку зору не поділяє І. І. Гуляєв, який вважає що «бренд як категорія творчої діяльності входить в сореру культури, але тим не менше поняття "культурний бренд" не є тавтологією, оскільки мова йде про культуру як про творчу сферу. [10, 38-45].

У роботах, що стосуються проблематики культурного брендування, не дається чіткого і однозначного визначення, яке б використовувалося всіма учасниками досліджень. Кучинська Т Н. [24, С.115-119] наголошує, що культурний бренд $€$ показником рівня розвитку культурної індустрії і стає ядром її конкурентоспроможності. Малькова В. К. та Тишков В. А. вважають, що культурний образбренд території має історичне та культурно-психологічне значення для жителів регіону, а також для 
«зовнішніх споживачів» $[17,21]$. Важеніна І.С. розглядає культурний бренд як сукупність функціональних і емоційних цінностей, що передбачають унікальний і позитивний досвід для споживача. Він відображає своєрідність характеристик даної території і спільноти [5, 92].

Якщо просування інтересів певного регіону здійснюється через просування бренду, то додаються «емоційні» складові - створення враження, зростання довіри, почуття симпатії до жителів регіону, повага до їх цінностей. Абушкін Р. Р., Проніна І. Н. [1, 33-40]. презентують культурний бренд території через впізнаваний набір символів місця, тобто тут прослідковується безпосередній зв'язок із культурним туризмом. Льовочкіна Н. А. розглядає регіональний культурний бренд [14, 57-62]. як ресурс просування регіону, який заснований на певній історико-культурній подію або пам'ятці культури, а також на видатній історичній особистості.

Концепція брендингу території виникає на основі швидко зростаючої кількості практик, тому кожен регіон, в силу індивідуальності свого розвитку, повинен мати власну стратегію стійкого розвитку, яка буде враховувати його сильні сторони [33, 484-488]. Замятін Д. Н. [13, 25-31] звертає увагу на прикладне використання геокультури території (регіональна ідентичність, історико-культурна спадщина і культурні ландшафти) за допомогою проектно-мережевої діяльності з метою фрормування і просування ефективного (атрактивного) територіального образу.

Брендинг територій (геобрендинг) - одне 3 актуальних напрямків сучасних стратегічних напрямків соціокультурного розвитку територіальних утворень, активізації інститутів туризму і гостинності на тій чи іншій території [26, 163-171]. Кожен регіон володіє унікальним набором брендових історико-культурних характеристик, включаючи особливості місцевого виробництва, традиції і звичаї, художні промисли [9]. Тому Хорольцева Е. Б. [30, 23-36] акцентує увагу на етнокультурних цінностях, образах, символах бренду, які мають стати ресурсом управління території.

Необхідність дослідження культурного брендування територій зумовлена багатьма причинами: активізується глобальна конкуренція між територіями на інвестиційному ринку, динамічно розвиваються туристичні зони, наявність власного бренду визнається одним з основних чинників ефективного розвитку і реалізації потенціалу міста, регіону, країни. Культурний брендинг стає процесом просування об'єктів культурної спадщини, що транслюють національні культурні цінності в світовому культурному просторі [27]. Розвиток потенціалу конкурентоспроможності території в постіндустріальному суспільстві має свої особливості. В питанні формування бренду багатьох країн, міст та традиційних промислових територій на перший план виходить пошук нових напрямків презентації територій, серед яких пропонується розвиток інноваційних секторів економіки і кластерів, інтелектуального потенціалу територій, що включає в себе відповідну інноваційну інфраструктуру, розвиток креативного сектора, що сприяє успішній трансформації міст через мистецтво, туризм та активне залучення стейкхолдерів у формування ідентичності культурного бренду [16]. Насичене культурне життя продовжує розглядатися як основна передумова до формування бренду, привабливого для креативного класу. Ряд міст вже зробив зусилля для її пожвавлення [40, 507-532]. Культурний брендинг території при його правильному розумінні стає досить ефективним інструментом актуалізації історико-культурної спадщини, а брендування територій в їх взаємозв'язку і при комплексному і диференційований підхід може призвести до нового імпульсу їх розвитку та єдності народів країни і світу. Так, Т.Л. Нагорняк пропонує розуміти під брендом країни комплексну торговельну марку, що має не тільки назву чи дизайнерське рішення, а ще й цілий комплекс асоціацій та ідентифікацій, через які сприймається споживачами [23, 220-228].

Один з найважливіших критеріїв привабливості бренду території - об'єкти культурної спадщини, які використовуються для створення туристичних дестинацій. Також вигадані персонажі літератури, кінематографу, театру сприяють підвищенню туристичної привабливості місця в цілому, що призводить до збільшення потоку туристів, зростання попиту на сувенірну продукцію, нарощуванню кількості робочих місць в туристичному секторі та т. п.[31, 3-12].

Послуги інституцій соціокультурної сфери спрямовані на те, щоб зробити локальні можливості максимально цікавими, корисними і потрібними як для внутрішнього, так і для зовнішнього споживача. «Культурний бренд» $є$ символічним капіталом території і дієвим методом економічної і культурної реабілітації географічного простору [20, 61-69]. Увага дослідників фріксується на виявленні ролі даних фракторів в оцінці ступеня привабливості тих чи інших країн і міст. Найчастіше такими чинниками виступають архітектура, світова популярність місця, творчі проекти та культурні традиції [35, 77-81].

У 1993 році вийшло перше видання знакової книги Філіпа Котлера, Дональда Хайдера і Ірвіна Рейну «Маркетинг територій: залучення інвестицій, промисловості і туризму в міста, штати і країни» [18]. Вони ж разом з К. Асплундом в 1999 році видали дослідження, присвячене досвіду застосування маркетингових технологій до соціальних сфер в європейських країнах, головним завданням яких стало підвищення туристичної привабливості місць, економічного і культурного розвитку міст і країн. У такій парадигмі культура, історія й соціальні відносини стають в один ряд з такими факторами територій, як економіка, інвестиції, туризм.

Автор терміну «бренд місця» Саймон Анхольт - видатний британський експерт національного брендингу, виділив шість основних компонентів бренду країни - «культура і традиції, люди, туризм та бажання відвідати країну, торгові марки експорту країни - товари і послуги, внутрішня і зовнішня 
політика, інвестиції та міграційне законодавство» [2, 36-44]. Виходячи з конкурентних переваг території до числа можливих стратегічних напрямків її позиціонування і подальшого просування можна віднести: культурно-історичні особливості; природно-географічну своєрідність; тематична спеціалізація на окремому виді діяльності; емоційний образ місця; проведення значущих міжнародних подій (культурних, спортивних, політичних); динамічний розвиток туризму [15].

3 визначення Всесвітньої організації туризму, саме сукупність емоційних і раціональних уявлень, що є результатом зіставлення усіх ознак країни, власного досвіду й чуток, впливає на створення певного образу про неї. Відповідно при згадуванні назви держави (бренду країни) відразу ж виникає цілий ланцюг асоціацій стосовно цієї країни Наприклад, Франція - бренд високої моди та вишуканого смаку, Швейцарія - “світовий сейф”, Австрія - країна музики, Данія - країна “казки” тощо [21].

Можна відзначити нові та інноваційні способи, які винаходять країни, щоб просунути себе, використовуючи глобальні спортивні події, щоб привернути увагу (відповідні кампанії щодо Олімпійських ігор); створюючи іконічні твори в царині культури та мистецтва (Канада - Cirque du Soleil, Об'єднані Арабські Емірати - музеї, парки розваг тощо) [22]. За останні кілька десятиліть чимало міст Європи виникли з креативних хабів. Прикладами можуть бути Більбао, Берлін, Амстердам, Гельсінкі, Копенгаген і Барселона. У цих містах культура була рушійною силою місцевого зростання і розвитку та призвела до зміни ландшафту культурного туризму [39].

Перші в світі проекти територіального брендингу були міськими, та й само поняття «бренд міста» виникло раніше поняття «бренд країни» або «бренд регіону» Бренд міста - це поняття, яке має соціогуманітарну основу, оскільки це не просто виявлення унікальності міста на основі позитивних асоціацій, - це формування самих асоціацій [36].

Деякі міста прагнуть продемонструвати світові свою «тему» - ідентичність, суть, особливість, в яскравих, привабливих образах, символах і унікальних подіях, цьому сприяє наявність значних і відомих культурних установ (музеїв, театрів), організація культурних заходів національного і міжнародного рівня, специфічний «дух місця», «краса місця», обумовлені просторовим характером [37, 129-131].

Протягом останніх десятиліть в економічно розвинених країнах спостерігається справжній бум тематичних (рольових) міст. Це міста Моцарта, Шекспіра, Ван Гога. Міста сирні, винні, ботанічні. Міські спільноти, і перш за все їх активні культурні і політичні еліти, прагнуть знайти цільну і красиву ідею для міста, консолідувати навколо неї населення міста і підвести під її реалізацію всі проекти з розвитку міста. Це призводить до високих результатів у вигляді поліпшення інвестиційного клімату, нових потоків туристів і нових жителів, корисних для місцевого ринку праці.

В умовах глобалізації урбанізовані центри, накопичують економічний, культурний й інформаційний потенціал суспільства, що створює передумови для формування вищих досягнень і зразків матеріальної й духовної культури. Звернення до унікальності міської культури, здійснення акценту на її глибокій історичності і цивілізаційній приналежності дозволяє місту отримати неповторне обличчя, яке приваблюватиме до нього туристів з усього світу.

Використання культурних брендів в сфері міського маркетингу відбувається за двома каналами: в'їзний туризм і експорт місцевих товарів і послуг. Туристичні компанії, мабуть, першими стали вживати вираз «бренд міста» [34, 2]. Міста набували за різні історичні часи особливого статусу бренду через такі характеристики міст, як: загальновідомі міста у світі (Париж), центри найвідоміших світових подій і проектів (Нью-Йорк), місця концентрації людей і ресурсів (Лос-Анджелес), перехрестя цивілізацій (Лондон), серце світових фрінансів, юридичних і політичних штаб-квартир (Женева), привабливе місце через перспективність бізнес пропозицій (Цюріх) місце провідних технологій (Сінгапур) та культурної унікальності (Пекін). Містам потрібні все нові і нові, нестандартні способи фрормування брендів і їх просування. Книга гарвардських економістів Дж. Пайна і Дж. Гілмора, написана в 1999 році, стала знаменита завдяки наведеній в ній ілюстрації: вартість двох однакових чашок кави різниться в рази, якщо одну з них випити в звичайній їдальні, а іншу - в кафе на площі Сан-Марко у Венеції.

Навіть міста з гарною репутацією проводять брендинг місця або території, щоб розкрити всі свої сильні сторони. Наприклад, Мельбурн, який вже вважався культурною столицею Австралії, після розробки бренду міста став привабливим для туристів і творчих особистостей з усього світу. Французький Ліон, який довгий час був центром гастрономічного туризму, спробував відійти від образів пов'язаних з кулінарією і тепер сприймається як центр освіти нарівні з Парижем. Іспанське місто Малага позиціонує себе не просто як курорт, а як батьківщина Пікассо, тому від відвідувачів немає відбою в будь-яку пору року.

Брендинг культурних явищ не зводиться лише до фрормування іміджу території або до підвищення туристичної, інвестиційної привабливості, конкурентності серед інших міст і країн. Брендинг в сфрері культури має за мету визволення максимального багатства смислів, ідей, цінностей конкретного феномена спадщини [11].

Використання потенціалу етнокультур і культурної спадщини країн і регіонів прискорює розвиток культурного туризму. При цьому туристи з різних країн все частіше відмовляються від традиційних місць відпочинку і вибирають маловідомі регіони. Це нове явище означає, що амбітні міста, формуючи уявлення про себе, повинні діяти активно, займатися персональним стратегічним позиціонуванням [12]. Процес капіталізації культури через туризм охопив не тільки такі великі мегаполіси, політичні і 
культурні столиці світу, як Відень, Париж, Прага, Лондон чи Берлін, а й зовсім невиразні в сенсі культурного потенціалу адміністративні одиниці. Як влучно зауважити один з апологетів концепції територіального маркетингу - Філіп Котлер, сьогодні навіть "порожні місця" долучаються до створення нових концептуальних пам'яток [18, 180-181], здатних стати їх візитною карткою. Не випадково нині спостерігається справжній бум виникнення великих і малих тематичних місць - ігрових, музикальних, театральних, гастрономічних та ін. Культивовані на основі культури ідеальні виміри простору перетворюють туристичну подорож на яскраву культурно-історичну подію.

Зокрема, Міністерство культури Хорватії розробило стратегію розвитку культурного туризму, яка передбачає використання культурного потенціалу не тільки приморської, але і континентальної частини країни. Взаємними зусиллями науковців, діячів культури, туристичних підприємств, власників готелів, бізнесменів культурні пам'ятки і події перетворюються на туристичний продукт, який урізноманітнює дозвілля туристів і сприяє їх більш тривалому перебуванню в країні. Схожі програми існують в Іспанії, Португалії, Італії, Болгарії та інших країнах.

У європейських країнах депресивні регіони розглядають культурну спадщину і культурний туризм як джерело розвитку. Інтеграція окремих пам'яток культурної спадщини в туристичну мережу стимулює затвердженню окремих програм реставрації, відкриття нових музеїв, ресторанів 3 традиційною кухнею, обладнання місцевими жителями гостьових кімнат для туристів. Для європейських країн є характерним рекламування власної культурної спадщини по телебаченню і радіо, стимулювання зацікавленості, проведення маркетингових досліджень різних цільових груп, використання новітніх технологій, зокрема надання можливості віртуального знайомства з пам'ятками культури.

Основною формою територіальної організації туристсько-рекреаційної діяльності виступають поселення, серед яких провідне місце займають малі історичні міста, як найбільші центри попиту туристичних послуг та їх пропозиції. У них зосереджено велику кількість пам'яток історії, культури та архітектури, які є привабливими екскурсійними об'єктами, в поєднанні з пам'ятками природи та садовопаркового мистецтва створюють найкращі передумови для розвитку туризму [8]. У більшості малих історичних міст, наявність рекреаційних ресурсів, особливо культурно-історичних, та значний працересурсний потенціал створюють можливості для формування туристсько-рекреаційного комплексу, розвиток якого сприятиме відновленню міст регіону та удосконаленню існуючої системи розселення.

В цьому контексті, на думку [3] слід звернути увагу на поняття історико-культурного регіону під час розробки іміджевих брендів та маршрутів за напрямом. Саме утворені культурно-історичними об'єктами простори певною мірою визначають локалізацію рекреаційних потоків і напрями екскурсійних маршрутів.

«Думай глобально, дій локально» - такий принцип містобудування став девізом нового феномену постсучасності - глокалізації. Автор поняття - британський соціолог Р. Робертсон [38], який відмітив, що чим сильніший пресинг глобальних стандартів поведінки і споживання, тим сильніша потреба територій (регіонів і особливо міст) шукати, культивувати і пред'являти світу свою унікальність. Щоб не розчинитися в потоці глобальної, усередненої маскультури, кожен регіон просто змушений створювати свій унікальний бренд, відомий в світовому контексті, максимально враховуючи культурні особливості споживача.[32]. В результаті глокалізації зростає культурна та архітектурна різноманітність місць [25]. Глобалізація підштовхнула до самопрезентації унікальної ідентичності міста і субрегіональні території (курортні та символічні зони - релігійного, історичного, освітнього плану), які здатні приваблювати туристів, абітурієнтів, партнерів та емігрантів іноді більш ніж сама країна. Контртенденція до локалізації зробила місцевість ще більш важливою, а туристичні напрямки все більше підкреслюють місцеві аспекти культури та побуту в їх маркетингу. Існує зростаюча потреба у відмінності у всіх сфрерах життя, яка спонукає невпинно шукати автентичність в різних країнах світу. Оскільки авіарейси все частіше перетворюють екзотику в повсякденне життя, для деяких пошук нових і різноманітних розробок тепер відбувається ближче до дому, у сільській місцевості Тоскани, на задніх вулицях Барселони або на Східному кінці Лондона.

На думку ряду вчених $[17,16]$ індивідуальність, унікальність є однією з ключових характеристик бренду, тому території необхідно відмовитися від комплексу типових характеристик, притаманних практично всіх регіонах (комерційні, соціальні, спортивні і т.д.), в користь більш вузької ексклюзивної спеціалізації.

Культурні бренди повинні ґрунтуватися на історико-культурних особистостях, пам'ятниках або на історико-культурні події, які мають відношення не тільки до культури і історії цього регіону, але і мають величезну вагу в історико-культурній спадщині країни. Особливо важлива роль у формуванні регіональних культурних брендів належить місцевим бібліотекам, архівам і музеям, які дозволяють представити культурно-історичний, природний, туристичний потенціал території.

\section{תimepamypa}

1. Абушкин Р. Р., Пронина И. Н. Культурный бренд республики Мордовия как проектная стратегия развития территории // Муниципалитет: экономика и управление. 2017. № 1 (22). С. 33-40.

2. Анхольт С. Создание бренда страны // Бренд- менеджер. 2007. №1. С. 36-44. 
3. Божко Л. Д. Культурний туризм як важливий чинник соціально-культурного розвитку регіонів України // Культура України. 2011. Вип. 32. URL: http://tourlib.net/statti_ukr/bozhko.htm (дата звернення: 05.06.2019).

4. Быстрова Т. Ю. Аксиология бренда: к методологии культурного брендинга территории // PR в изменяющемся мире: региональный аспект : сб. статей / под ред. М. В. Гундарина, А. Г. Сидоровской. Барнаул : Алтайский университет, 2011. Вып. 9. С. 85-95.

5. Важенина И. С. Бренд территории: сущность и проблемы формирования // Маркетинг в России и за рубежом. 2012. № 2. С. 92.

6. Визгалов Д. В. Брендинг города. Москва : Фонд Институт экономики города, 2011. 160 с.

7. Власова Н. Ю. Культурное наследие и искусство как составляющие брендинга городов // Известия УрГЭУ. 2011. № 6 (38). URL: https://cyberleninka.ru/article/n/kulturnoe-nasledie-i-iskusstvo-kak-sostavlyayuschiebrendinga-gorodov (дата обращения: 12.06.2019).

8. Головко О. М., Брецко Е. Ю. Перспективні напрями розвитку туризму в малих містах // Науковий вісник НЛтУ України . 2013. № 14. URL: https://cyberleninka.ru/article/n/perspektivni-napryami-rozvitku-turizmu-vmalih-mistah (дата звернення: 05.06.2019).

9. Горлова И. И., Бычкова О. И., Костина Н. А. Этнокультурный брендинг территории как ресурс влияния региональной культурной политики // Культурное наследие России. 2018. № 3. URL: https://cyberleninka.ru/article/n/etnokulturnyy-brending-territorii-kak-resurs-vliyaniya-regionalnoy-kulturnoy-politiki (дата обращения: 12.06.2019).

10. Гуляев И. И., Лиховец К. В. Культурный брендинг и теоретические основы территориального брендинга // Социологические науки. 2016. № 48. С. 38-45.

11. Гуцалов А. А. Культурный бренд и брендинг территории // Культурное наследие России. 2018. № 3. URL: https://cyberleninka.ru/article/n/kulturnyy-brend-i-brending-territorii (дата обращения: 05.06.2019).

12. Динни К. Брендинг территорий. Лучшие мировые практики / под ред К. Динни; пер. с анг. В. Сечной. Москва : Манн, Иванов и Фербер, 2013. 336 с.

13. Замятин Н. Д. Геокультурный брендинг городов и территорий: от гения места к имиджевым ресурсам // Современные проблемы сервиса и туризма. 2015. Вып. 2. С. 25-31.

14. Левочкина Н. А. Региональные культурные бренды как тренд развития территорий // Экономика и социум : е-Журнал / Издательский центр «ИУСЭР». Саратов, 2015. № 3 (16). URL : http://iupr.ru/domains_data/files/sborniki_jurnal/Zhurnal\%20_3(16)\%202015\%202.pdf. (дата обращения: 08.07.2019).

15. Логунцова И. В. Теоретические обоснования создания сильных брендов современных территорий // $\begin{array}{lllll}\text { Государственное управление. Электронный вестник. } 2012 . & \text { № } 33 .\end{array}$ https://cyberleninka.ru/article/n/teoreticheskie-obosnovaniya-sozdaniya-silnyh-brendov-sovremennyh-territoriy (дата обращения: 05.06.2019).

16. Лэндри Ч. Креативный город. Москва : Классика-XXI, 2011. 399 с.

17. Малькова В. К., Тишков В. А. Антропология историко-культурных брендов территорий, регионов и мест // Культура и пространство. Кн. 2 : Историко-культурные бренды территорий, регионов и мест / под ред. В. К. Мальковой, В. А. Тишкова. Москва : ИЭА РАН, 2010. С. 27-62.

18. Маркетинг мест. Привлечение инвестиций, предприятий, жителей и туристов в города, коммуны, регионы и страны Европы / Ф. Котлер, К. Асплунд, И. Рейн, Д. Хайдер; пер. с англ. М. Акая. Санкт-Петербург : Стокгольм. школа экономики в Санкт-Петербурге, 2005. 376 с.

19. Мельниченко С. В., Авдан О. Г. Брендинг у туристичному бізнесі: теоретичні аспекти // Туризм в умовах глобалізації: особливості та перспективи розвитку : монографія / під ред. М. О. Кизима, В. С. Єрмаченка. Харків : ВД ІнЖЕк, 2012. С. 211-224.

20. Мещеряков Т. В. Бренд территории как символический капитал // Креативная экономика. 2008. № 8 (20). C. $61-69$.

21. Мирошниченко В. Національний брендинг України. URL : http://www./ innovations.com.uavua/articles/14169/temp (дата звернення : 03.07.2019).

22. Нагорняк Т. Л. Бренди країн світу. Імідж українських регіонів у контексті розбудови бренда "Україна". URL :http://www./ social-science.com.uа (дата звернення : 03.07.2019).

23. Нагорняк Т. Л. Країна як бренд. Національний бренд “Україна”// Стратегічні пріоритети. 2008. № 4 (9). C. 220-228.

24. Ни Цзяоцзяо, Кучинская Т. Н. Культурный брендинг в репрезентативных практиках китайской мягкой силы // Дискурс-Пи. 2017. № 3-4 (2829), т. 14. С. 115-119.

25. Смирнягин Л. О региональной идентичности // Пространство и время в мировой политике и международных отношениях : матер. 4 Конвента РАМИ : в 10 т. Т. 2 : Идентичность и суверенитет: новые подходы к осмыслению понятий / под ред. И. М. Бусыгиной. Москва : МГИМО-Университет, 2007. С. 81-107.

26. Старостова Л. Э. Брендинг территории: проблема поиска ценностных оснований // Известия Уральского федерального университета. Сер. 1: Проблемы образования, науки и культуры. 2014. Т. 129, № 3. С. 163171.

27. Старцева А. С. Культурный брендинг имиджа российских регионов: традиции и новации : дис. ...канд. культурологии : 24.00.01. Москва, 2015. 185 с.

28. Столкновение культур: глобализация не отменяет разнородность. Точка зрения Millward Brown // Электронная публикация: Центр гуманитарных технологий. URL: https://gtmarket.ru/laboratory/expertize/2009/2229 (дата обращения: 18.08.2019).

29. Фенько А. Б. Туризм как показатель социального статуса // Социологические исследования. 2007. № 2. C. $125-131$.

30. Хорольцева Е. Б. Проектирование этнокультурного бренда региона как ресурс управления развитием территории // Среднерусский вестник общественных наук. Сер.: Социология. 2018. № 2, т. 13. С. $23-36$.

31. Шекова Е. Л. Особенности маркетинга в сфере культуры // Маркетинг в России и за рубежом. 2001. № 3. C. 3-12. 
32. Штепа B. RUтопия. Екатеринбург : Ультра. Культура, 2004. 384 с.

33. Якубова Т. Н., Крюкова А. П. Территориальный брендинг как инструмент развития региона // Молодой ученый. 2014. № 21. С. 484-488.

34. Anholt S. Place branding: Is it marketing, or isn't it? // Editorial. Place Branding and Public Diplomacy. 2010. № 1. P. 2.

35. Compte-Pujol M. The importance of heritage on the overall perceived image of a place: Barcelona seen by its residents // Брендинг малых и средних городов России: опыт, проблемы, перспективы : матер. Всероссийской научн.-практ. конф. Екатеринбург : Уральский университет, 2015. С. 77-81.

36. Kavaratzis M. From City Marketing to City Branding. An Interdisciplinary // Analysis with Reference to Amsterdam, Budapest and Athens. PhD Thesis, University of Gronongen, 2008. P. 53.

37. Marszal T. Someremarkson metropolitan development // StudiaRegionalia. Urban and regional development - concepts and experiences. Warszawa, 2004. V. 14. S. 129-131.

38. Robertson R. Globalization: Social Theory and Global Culture. L. : Sage, 1992.

2009.

39. Zukin, S. Naked City: The Death and Life of Authentic Urban Places. Oxford University Press, Oxford,

40. Peel D., Lloyd G. New communicative challenges: Dundee, place branding and the reconstruction of a city image. Town Planning Review. 2008. Vol. 79. No. 5. P. 507-532.

\section{References}

1. Abushkin, R.R. \& Pronina, I.N. (2017). The Cultural Brand of the Republic of Mordovia as a Design Strategy for the Development of the Territory. Municipality: Economics and Management, 1 (22), 33-40 [in Russian].

2. Anholt, S.( 2007). Creating a country brand. Brand manager,1, 36-44 [in Russian].

3. Bozhko, L.D (2011). Cultural tourism as an important factor of socio-cultural development of Ukrainian regions. Culture of Ukraine. Is. 32. URL: http://tourlib.net/statti_ukr/bozhko.htm (accessed 05/06/2019) [in Ukrainian].

4. Bystrova, T. (2011). Yu. Axiology of Brand: Towards a Methodology for Cultural Branding of the Territory. PR in a Changing World: A Regional Aspect: Sat. articles. MV Gundarin, AG Sidorovskaya (Eds.). Barnaul: Altai University, Iss. 9, 85-95 [in Russian].

5. Vazhenina, I.S. (2012). Brand territory: the essence and problems of formation. Marketing in Russia and abroad, 2. 92 [in Russian].

6. Vizgalov, D.V. (2011). City branding. Moscow: Foundation for the Institute of City Economics [in Russian].

7. Vlasova N. Yu. (2011). Cultural heritage and art as components of city branding. Izvestiya UrGEU. 6 (38). URL: https://cyberleninka.ru/article/n/kulturnoe-nasledie-i-iskusstvo-kak-sostavlyayuschie-brendinga-gorodov (accessed: 12/06/2019) [in Russian].

8. Holovko, O.M, \& Bretsko, E. Yu. (2013). Perspective directions of tourism development in small cities. Scientific Bulletin of NLTU of Ukraine, 14. URL: https://cyberleninka.ru/article/n/perspektivni-napryami-rozvitku-turizmu-vmalih-mistah (accessed: 06/05/2019) [in Ukrainian].

9. Gorlova, I.I., Bychkova. O.I., \& Kostina N.A. (2018). Ethno-cultural branding of the territory as a resource of influence of regional cultural policy. Cultural Heritage of Russia, 3. URL: https://cyberleninka.ru/article/n/etnokulturnyybrending-territorii-kak-resurs-vliyaniya-regionalnoy-kulturnoy-politiki (accessed 2/06/2019) [in Russian].

10. Gulyaev, I.I., \& Likhovets, K.V. (2016). Cultural branding and theoretical foundations of territorial branding. Sociological Sciences, 48, 38-45 [in Russian].

11. Gutsalov, A.A. (2018). Cultural branding and territory branding. Cultural Heritage of Russia, 3. URL: https://cyberleninka.ru/article/n/kulturnyy-brend-i-brending-territorii (accessed: 05/06/2019) [in Russian].

12. Dinney, K. (2013). Branding territories. Best practices in the world. K. Dinney (Ed.). (V. Sechnoy Trans. with eng.). Moscow: Mann, Ivanov, and Ferber [in Russian].

13. Zamyatin, N.D (2015). Geocultural branding of cities and territories: from the genius of a place to image resources. Modern problems of service and tourism. Issue. 2, 25-31 [in Russian].

14. Levochkina, N.A. (2015). Regional cultural brands as a trend of territorial development. Economy and society: e-Journal. IUSER Publishing Center. Saratov, 3(16). http://iupr.ru/domains_data/files/sborniki_jurnal/Zhurnal\%20_3(16)\%202015\%202.pdf (date of access: 08/07/2019) [in Russian].

15. Loguntsova, I.V (2012). Theoretical substantiation of creation of strong brands of modern territories. Public administration. The electronic newsletter, 33. URL: https://cyberleninka.ru/article/n/teoreticheskie-obosnovaniyasozdaniya-silnyh-brendov-sovremennyh-territoriy (accessed 05/06/2019) [in Russian].

16. Landry, C. (2011). The creative city. Moscow: Classic-XXI [in Russian].

17. Malkova, V.K., \& Tishkov, V.A. (2010). Anthropology of historical and cultural brands of territories, regions and places. Culture and Space. Book. 2: Historical and Cultural Brands of Territories, Regions and Places. V.K. Malkova, V.A. Tishkova (Eds.). Moscow: IEA RAS, pp. 27-62 [in Russian].

18. Marketing of places. Attracting investments, businesses, residents and tourists to cities, communes, regions and countries of Europe. F. Kotler, K. Asplund, I. Rein, D. Haider; (M. Okaya, Trans. with English). St. Petersburg: Stockholm. School of Economics, St. Petersburg, 2005 [in Russian].

19. Melnichenko S.V., \& Avdan, A.G. (2012). Branding in the tourism business: theoretical aspects. Tourism in the conditions of globalization: features and prospects of development: monograph. M.O Kizima, V.S Yermachenko (Eds.). Kharkiv: Pp. 211-224 [in Ukrainian].

20. Meshcheryakov, T.V. (2008). Branding the Territory as Symbolic Capital, Creative Economics, 8 (20), 6169 [in Russian].

21. Miroshnichenko, V. National branding of Ukraine. URL: http://www./ innovations.com.ua sua / articles / 14169 / temp (accessed 03/07/2019) [in Ukrainian].

22. Nagornyak, T.L. Brands of the countries of the world. The image of the Ukrainian regions in the context of building the "Ukraine" brand. URL: http: //www./ social-science.com.ua (accessed: 03/07/2019) [in Ukrainian]. 